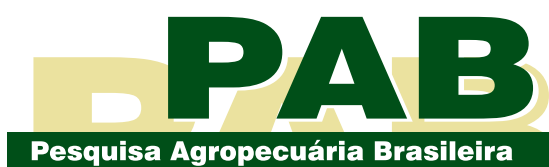

ISSN 1678-3921

Journal homepage: www.embrapa.br/pab

For manuscript submission and journal contents, access: www.scielo.br/pab

\section{Selection gains for bunch production in interspecific hybrids between "caiaué" and oil palm}

\begin{abstract}
The objective of this work was to estimate selection gains for bunch production in hybrids obtained from "caiaué" (Elaeis oleifera) parents from the Manicoré population and oil palm (Elaeis guineensis) parents from the La Mé population, from the third to the eighth year after planting. Thirtynine full-sibling progenies were evaluated in experiments conducted in a randomized complete block design, with four replicates and 12 plants per plot. The genetic gain estimates were $27.6 \%$ for the ten best selected F1 individuals, $13.7 \%$ for the four best selected progenies from parents of both sexes, $6.4 \%$ for the selected progenies of the five best male parents, $6.0 \%$ for the selected progenies of the two best families from male parents, and $4.0 \%$ for the selected progenies of the best descendants from male parents. Genetic gains for bunch production can be achieved, in the short term, through selection restricted to male parents, and, in the medium term, through selection of both male and female parents and cloning of $\mathrm{F} 1$ individuals.
\end{abstract}

Index terms: Elaeis guineensis, Elaeis oleifera, bunch production, plant breeding, REML/BLUP.

\section{Ganhos de seleção para produção de cachos em híbridos interespecíficos entre caiaué e dendê}

Resumo - O objetivo deste trabalho foi estimar ganhos de seleção para produção de cachos em híbridos obtidos de genitores caiaué (Elaeis oleifera) da população Manicoré e dendê (Elaeis guineensis) da população La Mé, do terceiro ao oitavo ano após o plantio. Avaliaram-se 39 progênies de irmãos completos em experimentos conduzidos em delineamento de blocos ao acaso, com quatro repetições e 12 plantas por parcela. As estimativas de ganho genético foram de 27,6\% para a seleção dos dez melhores indivíduos F1, 13,7\% para a seleção das quatro melhores progênies de genitores de ambos os sexos, $6,4 \%$ para a seleção das progênies dos cinco melhores genitores masculinos, 6,0\% para a seleção das progênies das duas melhores famílias de genitores masculinos e 4,0\% para a seleção das progênies da melhor descendência de genitores masculinos. É possível obter ganhos genéticos para produção de cachos, em curto prazo, com a seleção restrita a genitores masculinos, e, em médio prazo, com a seleção de genitores masculinos e femininos e com a clonagem de indivíduos F1.

Termos para indexação: Elaeis guineensis, Elaeis oleifera, produção de cachos, melhoramento genético de plantas, REML/BLUP. 


\section{Introduction}

Palm oil is extracted from the mesocarp of the fruit of oil palm (Elaeis guineensis Jacq.), a palm tree of African origin. It is the most produced and commercialized vegetable oil worldwide (FAO, 2017), mainly due to the species highest oil productivity among the grown oilseeds, its low production costs, and its multiple uses in the chemical, cosmetic, and food industries (Zimmer, 2009).

Native to the American continent, the "caiaué" [Elaeis oleifera (Kunth) Cortés] palm belongs to the same genus as E. guineensis and produces a similar oil, but with several other favorable characteristics, such as higher antioxidant concentrations, lower lipase enzyme activity, and higher unsaturated fatty acid content (Cadena et al., 2013; Lieb et al., 2017). However, the mesocarp of caiaué fruits is smaller and has a lower oil content than that of the African species (Lieb et al., 2017), which partly explains its lower potential for oil production despite the better quality of the oil produced from it.

The interspecific hybridization between caiaué and oil palm has been explored for genetic improvement, mainly to introduce caiaué-associated resistance to lethal yellowing into oil palm (Lopes et al., 2012). Lethal yellowing is a disorder of undefined etiology that has already decimated thousands of hectares of oil palm plantations in the Americas, including in Brazil (De Franqueville, 2003). Therefore, due to its inherited resistance to lethal yellowing, the interspecific hybrid between caiaué and oil palm (IEH $\mathrm{O} \times \mathrm{G}$ ) is currently the only option for oil palm cultivation in areas where the disease occurs (Cunha \& Lopes, 2010). Because the total weight of the bunches produced by oil palm cultivars is the main determinant of oil yield (Okwuagwu et al., 2008; Okoye et al., 2009), gains in bunch production are important for both the intra- and interspecific improvement of oil palm.

IEH $\mathrm{O} \times \mathrm{G}$ progenies, from female caiaué and male oil palm plants of the Manicoré and La Mé populations, respectively, have shown a high potential for bunch production, with a high genetic variability for this characteristic, from the third to the sixth year after planting (Gomes Junior et al., 2016). Those progenies were derived from the same caiaué and oil palm populations used to develop the BRS Manicoré cultivar (Cunha \& Lopes, 2010), which is the only IEH $\mathrm{O} \times \mathrm{G}$ grown in Brazil to date. This is an indicative that selection gains for bunch production can be obtained using caiaué and oil palm parents from the Manicoré and La Mé populations, respectively, possibly exceeding the productivity of the BRS Manicore cultivar. Genetic gains with selection can be assessed based on bunch production in the first years of crop production, whereas production potential and selection gains for the adult stage of the crop can be estimated up to the eighth year after planting, when the production peak is reached (Chia et al., 2009).

The objective of this work was to estimate selection gains for bunch production in hybrids obtained from caiaué parents from the Manicoré population and oil palm parents from the La Mé population, from the third to the eighth year after planting.

\section{Materials and Methods}

The experiments were set up at Marborges Agroindústria S.A., in the municipality of Moju, in the state of Pará, Brazil (1 $\left.{ }^{\circ} 58^{\prime} 42^{\prime \prime} \mathrm{S}, 48^{\circ} 36^{\prime} 50^{\prime \prime} \mathrm{W}\right)$, in February 2007. The soil of the site is a Latossolo Amarelo distrófico franco-arenoso (Santos et al., 2013), i.e., a dystrophic sandy loam Oxisol. The climate is Af according to Köppen's classification (Alvares et al., 2013), with an average rainfall of 2,850 $\mathrm{mm}$ from 1994 to 2015 and a rainy season that occurs in the first half of the year.

A total of $39 \mathrm{~F} 1$ full-sibling progenies were obtained from crosses between 32 caiaué females, all from 18 different families of the Manicore population, and 13 oil palm males, 7 from three different LM 10T families and 6 from four different LM 2T families of the La Mé population (Table 1). These caiaué and oil palm populations were maintained at the Rio Urubu experimental field, located in the municipality of Rio Preto da Eva, in the state of Amazonas, and were used to produce commercial seeds of 'BRS Manicoré', an interspecific F1 hybrid launched by Embrapa in 2010 (Cunha \& Lopes, 2010) and registered at Registro Nacional de Cultivares (RNC) (Brasil, 2019) under number 26031.

The progenies were divided into three experimental groups, two with 14 and one with 15 progenies; 2 progenies (RUB 1195 and RUB 1213) were common to the three experiments. The experimental design was a randomized complete block, with four replicates and 12 plants per plot (four rows of three plants each). As a

Pesq. agropec. bras., Brasília, v.54, e00819, 2019

DOI: 10.1590/S1678-3921.pab2019.v54.00819 
Table 1. Genealogy of the 39 assessed progenies of caiaué (Elaeis oleifera) and oil palm (Elaeis guineensis) interspecific hybrids.

\begin{tabular}{|c|c|c|c|c|c|c|}
\hline \multirow[t]{2}{*}{ Progeny } & \multicolumn{2}{|c|}{ Caiaué (female parent) } & \multicolumn{3}{|c|}{ Oil palm (male parent) } & \multirow[t]{2}{*}{ Experiment } \\
\hline & Family & Parent & Progeny & Family & Parent & \\
\hline RUB 1198 & RUC 107 & RU $2842 \mathrm{D}$ & LM $2 \mathrm{~T}$ & LM 12437 & RU $2707 \mathrm{P}$ & 3 \\
\hline RUB 1226 & RUC 102 & RU $78 \mathrm{D}$ & LM 2 T & LM 12785 & RU 53 P & 1 \\
\hline RUB 1271 & RUC 224 & RU 1578 D & LM 2 T & LM 13582 & RU $2691 \mathrm{P}$ & 1 \\
\hline RUB 1210 & RUC 76 & RU 3308 D & LM 2 T & LM 13582 & RU $2691 \mathrm{P}$ & 2 \\
\hline RUB 1227 & RUC 102 & RU 2846 D & LM 2 T & LM 13582 & RU $2692 \mathrm{P}$ & 1 \\
\hline RUB 1283 & RUC 103 & RU 92 D & LM $2 \mathrm{~T}$ & LM 13582 & RU 2692 P & 1 \\
\hline RUB 1196 & RUC 107 & RU $2841 \mathrm{D}$ & LM $2 \mathrm{~T}$ & LM 13582 & RU $2692 \mathrm{P}$ & 3 \\
\hline RUB 1274 & RUC 224 & RU 1578 D & LM $2 \mathrm{~T}$ & LM 13582 & RU 2692 P & 1 \\
\hline RUB 1199 & RUC 109 & RU 3099 D & LM 2 T & LM 13582 & RU $2693 \mathrm{P}$ & 3 \\
\hline RUB 1211 & RUC 76 & RU $3111 \mathrm{D}$ & LM 2 T & LM 13582 & RU 2693 P & 2 \\
\hline RUB 1218 & RUC 79 & RU $2900 \mathrm{D}$ & LM 2 T & LM 13582 & RU $2693 \mathrm{P}$ & 2 \\
\hline RUB 1219 & RUC 79 & RU $2901 \mathrm{D}$ & LM 2 T & LM 13582 & RU 2693 P & 2 \\
\hline RUB 1208 & RUC 80 & RU 2905 D & LM 2 T & LM 13582 & RU 2693 P & 3 \\
\hline RUB 1232 & RUC 104 & RU 3079 D & LM 2 T & LM 13582 & RU 2749 P & 1 \\
\hline RUB 1202 & RUC 93 & RU 1608 D & LM 2 T & LM 13582 & RU 2749 P & 3 \\
\hline RUB 1234 & RUC 105 & RU 3189 D & LM $10 \mathrm{~T}$ & LM 12011 & RU $2710 \mathrm{P}$ & 1 \\
\hline RUB 1201 & RUC 109 & RU 3089 D & $\mathrm{LM} 10 \mathrm{~T}$ & LM 12011 & RU 2710 P & 3 \\
\hline RUB 1221 & RUC 114 & RU $101 \mathrm{D}$ & LM $10 \mathrm{~T}$ & LM 12011 & RU $2710 \mathrm{P}$ & 2 \\
\hline RUB 1223 & RUC 224 & RU $1578 \mathrm{D}$ & LM $10 \mathrm{~T}$ & LM 12011 & RU $2710 \mathrm{P}$ & 2 \\
\hline RUB 1213 & RUC 76 & RU 1724 D & LM $10 \mathrm{~T}$ & LM 12011 & RU $2710 \mathrm{P}$ & 1,2 , and 3 \\
\hline RUB 1204 & RUC 96 & RU 3170 D & LM $10 \mathrm{~T}$ & LM 12011 & RU $2710 \mathrm{P}$ & 3 \\
\hline RUB 1225 & RUC 102 & RU $2839 \mathrm{D}$ & LM $10 \mathrm{~T}$ & LM 12011 & RU 56 P & 1 \\
\hline RUB 1231 & RUC 103 & RU 92 D & LM $10 \mathrm{~T}$ & LM 12011 & RU 56 P & 1 \\
\hline RUB 1233 & RUC 104 & RU $3101 \mathrm{D}$ & LM $10 \mathrm{~T}$ & LM 12011 & RU 56 P & 1 \\
\hline RUB 1195 & RUC 107 & RU $1604 \mathrm{D}$ & LM $10 \mathrm{~T}$ & LM 12011 & RU 56 P & 1,2 , and 3 \\
\hline RUB 1203 & RUC 95 & RU $1778 \mathrm{D}$ & LM $10 \mathrm{~T}$ & LM 12252 & RU $2698 \mathrm{P}$ & 3 \\
\hline RUB 1212 & RUC 76 & RU $3111 \mathrm{D}$ & LM $10 \mathrm{~T}$ & LM 12252 & RU $2700 \mathrm{P}$ & 2 \\
\hline RUB 1214 & RUC 77 & RU 2914 D & LM $10 \mathrm{~T}$ & LM 12252 & RU $2700 \mathrm{P}$ & 2 \\
\hline RUB 1215 & RUC 78 & RU 3359 D & $\mathrm{LM} 10 \mathrm{~T}$ & LM 12252 & RU $2700 \mathrm{P}$ & 2 \\
\hline RUB 1205 & RUC 96 & RU 3123 D & LM $10 \mathrm{~T}$ & LM 12252 & RU $2700 \mathrm{P}$ & 3 \\
\hline RUB 1206 & RUC 96 & RU 3169 D & LM $10 \mathrm{~T}$ & LM 12252 & RU $2700 \mathrm{P}$ & 3 \\
\hline RUB 1209 & RUC 43 & RU $2787 \mathrm{D}$ & LM $10 \mathrm{~T}$ & LM 12252 & RU 2733 P & 2 \\
\hline RUB 1224 & RUC 102 & RU $2845 \mathrm{D}$ & LM $10 \mathrm{~T}$ & LM 13751 & RU $2729 \mathrm{P}$ & 2 \\
\hline RUB 1197 & RUC 107 & RU $2842 \mathrm{D}$ & LM $10 \mathrm{~T}$ & LM 13751 & RU 2730 P & 3 \\
\hline RUB 1200 & RUC 109 & RU 3089 D & LM $10 \mathrm{~T}$ & LM 13751 & RU 2730 P & 3 \\
\hline RUB 1217 & RUC 224 & RU $1578 \mathrm{D}$ & LM $10 \mathrm{~T}$ & LM 13751 & RU 2730 P & 2 \\
\hline RUB 1220 & RUC 79 & RU $1588 \mathrm{D}$ & LM $10 \mathrm{~T}$ & LM 13751 & RU 2730 P & 2 \\
\hline RUB 1277 & RUC 79 & RU $1586 \mathrm{D}$ & LM $10 \mathrm{~T}$ & LM 13751 & RU $2730 \mathrm{P}$ & 1 \\
\hline RUB 1250 & RUC 97 & RU 1605 D & LM $10 \mathrm{~T}$ & LM 13751 & RU $2730 \mathrm{P}$ & 1 \\
\hline
\end{tabular}


border, a line - with one plant at each end - was used at each end of the experimental plots. Planting was done at a density of 143 plants per hectare in a contiguous area of 17.6 ha. It should be noted that no researchbased production system has yet been established for IEH $\mathrm{O} \times \mathrm{G}$ cultivation, although there are some technical recommendations for seedling formation, for example (Gomes Junior et al., 2017). Therefore, producers have adapted the recommendations for oil palm cultivars obtained from empirical experiments in the cultivated areas (Menezes et al., 2017). In the present study, the management practices used were those adapted by Marborges Agroindústria S.A. to manage their cultivated areas, as described in Pina (2010).

Mature bunches were harvested at 15- to 20-day intervals from July 2010 (third year after planting) to December 2015 (eighth year after planting), with a total of 111 harvests in the 5.5 experimental years. The number and weight of the bunches produced per plant in each harvest were recorded, and weighing was performed in the field using a dynamometer. During the assessment, 56 plants (2.4\% of the total) were excluded due to mortality, abnormal vegetative development, nutritional deficiency, or severe disease incidence. Bunch production per plant $\left(\mathrm{PROD}_{\text {ind }}\right)$, expressed in kilogram of fresh fruit bunches (FFB) per plant per year, was converted to production by area and expressed in Mg FFB per hectare per year, based on a planting density of 143 plants per hectare.

The genetic parameters were estimated by the restricted maximum likelihood/best linear unbiased prediction (REML/BLUP) mixed-effect model, using the Selegen-REML/BLUP software (Resende, 2002), through the following statistical model: $\mathrm{y}=\mathrm{Xr}+\mathrm{Zg}+$ $\mathrm{Wp}+\mathrm{Tb}+\mathrm{e}$, where $y$ represents the data; $r$ are the fixed population effects added to the overall mean, including the population and common control means; $g$ are the random genetic effects; $p$ are the random plot effects; $\mathrm{b}$ are the random block effects; e are the random errors or residues; and X, Z, W, and T represent the incidence matrices for the $r, g, p$, and $b$ effects, respectively.

The genotypic values for male parents $\left(G_{p}\right)$, as well as for their families and progenies, were estimated according to the equations:

$$
\begin{aligned}
& \mathrm{h}^{2}=\left(\mathrm{N}_{\mathrm{p}} \times\left(\mathrm{PA}_{\mathrm{m}}\right)^{2}\right) /\left(1+\left(\left(\mathrm{N}_{\mathrm{p}}-1\right) \times\left(\mathrm{PA}_{\mathrm{m}}\right)^{2}\right)\right) \\
& \text { and } \mathrm{GV}_{\mathrm{p}}=\left(\mathrm{GV}_{\mathrm{m}} \times \mathrm{h}^{2}{ }_{\mathrm{m}} /\left(\mathrm{PA}_{\mathrm{m}}\right)^{2} \times\left(\mathrm{GV}_{\mathrm{pm}} / \mathrm{GV}_{\mathrm{mm}}\right)\right. \text {, }
\end{aligned}
$$

where $\mathrm{N}_{\mathrm{p}}$ is the number of progenies represented by the parent, $\mathrm{PA}_{\mathrm{m}}$ is the mean progeny accuracy represented by the parent, $\mathrm{GV}_{\mathrm{m}}$ is the mean genotypic value for the progenies represented by the parent, $\mathrm{h}_{\mathrm{m}}{ }_{\mathrm{m}}$ is the mean heritability of the progenies represented by the parent, $\mathrm{GV}_{\mathrm{pm}}$ is the overall mean of the $\mathrm{GV}_{\mathrm{p}}$ of all the parents of the experiment, and $\mathrm{GV}_{\mathrm{mm}}$ is the overall mean of the $\mathrm{GV}_{\mathrm{m}}$ of all the progenies of the experiment.Selection gains for bunch production were estimated for progenies from: female caiaué and male oil palm parents from the Manicoré and La Mé populations, respectively; only male parents, considering the selection of parent, family, and progeny; and F1 individuals for vegetative propagation. Assessing selection gain for male parents is interesting because this strategy allows bringing a new cultivar to the market faster, despite the lower genetic gain, compared with selection for both males and females, due to the great pollen production capacity of the oil palm plants used as male parents in hybridization. According to the statistics obtained at the seed production area at the Rio Urubu experimental field, a single parent can produce up to $50 \mathrm{~g}$ pollen per year, which is enough to pollinate 800 female caiaué inflorescences. Considering that each caiaué inflorescence produces a bunch with an average of 500 seeds, the pollen of a single male parent can produce approximately 400,000 seeds per year. Moreover, a caiaué plant used as a female parent in interspecific hybridization produces between five and ten bunches per year, with an average of 500 seeds each, resulting in 2,500 to 5,000 seeds per year. However, it should be pointed out that, to commercially reproduce superior progenies, the parents must be propagated, especially the females, which delays cultivar release but allows a greater genetic gain.

\section{Results and Discussion}

The low values observed for the coefficients related to the plot effects $\left(\mathrm{c}^{2}\right.$ parc $\left.=2.9 \%\right)$ and to the genotype $\times$ environment interaction $\left(\mathrm{c}^{2}{ }_{\text {int }}=0.1 \%\right)$ indicate a good experimental accuracy (Table 2) based on the classification of Resende (2007).

The overall mean of the genotypic values $(\mu \mathrm{GV})$ for $\mathrm{PROD}_{\text {ind }}$ for all individual plants in the experiment was $157.1 \mathrm{~kg}$ FFB per plant per year, which corresponds to 22.5 Mg FFB per hectare per year (Table 2), indicating the high production potential of the progenies. It 
should be highlighted that these values were obtained based on bunch production from the third to the eighth year after planting, including the juvenile period from the third to the fifth year, when plant production is still below the potential of the adult stage. This explains why the values in the present study were higher than the overall mean of $20.6 \mathrm{Mg}$ FFB per hectare per year found by Gomes Junior et al. (2016) when assessing the same progenies but only from the third to the sixth year of cultivation. Also in the municipality of Rio Preto da Eva, Lopes et al. (2012) assessed 59 IEH O $\times$ G adult-stage progenies from the seventh to the thirteenth year after planting and obtained genotypic values of $127.8,128.9,141.3,144.6$, and $150.4 \mathrm{~kg}$ FFB per plant per year for the five best progenies derived from different caiaué (Manicoré, Caimbé-Tefé, UEPAEManaus, and BR 174) and oil palm (Deli, La Mé, and Nigéria) populations. According to these authors, bunch production in Manicoré $\times$ LM $2 \mathrm{~T}$ plants was

Table 2. Estimates of the genetic parameters for bunch production ( $\mathrm{kg}$ per plant per year) from the third to the eighth year after planting in the field of 39 progenies of caiaué (Elaeis oleifera) and oil palm (Elaeis guineensis) interspecific hybrids.

\begin{tabular}{lc}
\hline Genetic parameter $^{(1)}$ & Estimate \\
\hline $\mathrm{V}_{\mathrm{g}}$ & 166.3 \\
$\mathrm{~V}_{\text {parc }}$ & 20.8 \\
$\mathrm{~V}_{\text {int }}$ & 0.53 \\
$\mathrm{~V}_{\text {within }}$ & 574.9 \\
$\mathrm{~V}_{\text {phe }}$ & 762.6 \\
$\mathrm{~h}^{2}$ & $0.44 \pm 0.06$ \\
$\mathrm{~h}^{2}{ }_{\mathrm{mc}}$ & 0.89 \\
$\mathrm{~h}^{2}{ }_{\text {ad }}$ & 0.29 \\
$\mathrm{c}^{2}{ }_{\text {parc }}$ & 0.029 \\
$\mathrm{c}^{2}{ }_{\text {int }}$ & 0.001 \\
$\mu \mathrm{GV}$ & 157.1 \\
$\mu \mathrm{PV}$ & 163.8 \\
\hline
\end{tabular}

${ }^{(1)} \mathrm{V}_{\mathrm{g}}$, genotypic variance between full-sibling progenies, equivalent to $1 / 2$ of the additive genetic variance plus $1 / 4$ of the dominance genetic variance, ignoring epistasis; $V_{\text {parc }}$, environmental variance between plots; $\mathrm{V}_{\text {int }}$, genotype variance $\times$ environment interaction; $\mathrm{V}_{\text {within }}$, residual variance within the plot; $V_{\text {phe }}$, individual phenotypic variance; $h^{2}$, individual narrow-sense heritability, obtained by ignoring the dominance genetic variance fraction $(1 / 4) ; \mathrm{h}^{2} \mathrm{mc}$, adjusted heritability of the mean genotype, assuming complete survival; $\mathrm{h}^{2}$ ad, additive heritability within a plot, obtained by ignoring the dominance genetic variance fraction $(1 / 4)$; $\mathrm{c}^{2}$ parc , coefficient to determine plot effects; $\mathrm{c}^{2}$ int, coefficient to determine genotype $\times$ environment interaction effects; $\mu \mathrm{GV}$, overall mean of genotypic values; and $\mu \mathrm{PV}$, overall mean of phenotypic values. particularly relevant, as four of the five most productive progenies were derived from this combination. However, the reported values were below the means for the progenies assessed in the present study, which may be explained by the fact that by Lopes et al. (2012) used different populations and combinations of caiaué and oil palm, whereas here only Manicoré $\times$ La Mé combinations were evaluated. The lower yields found by the authors may also be partly due to the assisted pollination performed in the present study during the entire assessment of bunch production, as well as to the genetically distinct progenies used and to the soil and climate differences between the experimental sites.

The estimates of genetic variability and heritability for $\mathrm{PROD}_{\text {ind }}$ were high, and the adjusted heritability of the genotypic mean $\left(\mathrm{h}^{2}{ }_{\mathrm{mc}}=0.89\right)$ was higher than both the individual narrow-sense heritability $\left(\mathrm{h}^{2}{ }_{\mathrm{a}}=\right.$ $0.44 \pm 0.06)$ and the additive heritability within a plot $\left(\mathrm{h}^{2}{ }_{\mathrm{ad}}=0.29\right)$ (Table 2). These parameters indicate that there were favorable conditions for gains with the selection of both progenies and individuals. High estimates for bunch production heritability in IEH $\mathrm{O} \times \mathrm{G}$ were also observed in previous studies (Lopes et al., 2012; Gomes Jr. et al., 2014; Gomes Junior et al., 2016), including one on an oil palm population with a wide genetic variability (Okwuagwu et al., 2008). However, a low heritability for bunch production in oil palm populations with a narrow genetic base has also been reported (Soh et al., 2003; Noh et al., 2010; Marhalil et al., 2013), showing the importance of hereditary factors for the genetic improvement of a crop.

The phenotypic values for the $\mathrm{PROD}_{\text {ind }}$ of the 39 progenies between the third and eighth year after planting ranged from 137.5 to $199.1 \mathrm{~kg}$ FFB per plant per year, while the genotypic values ranged from 132.0 to $187.7 \mathrm{~kg}$ FFB per plant per year. Progenies RUB 1199, RUB 1218, RUB 1205, and RUB 1209 stood out, showing genotypic values of 187.7, 176.3, 175.3, and $174.8 \mathrm{~kg}$ FFB per plant per year, respectively, which are equivalent to $26.8,25.2,25.1$, and $25.0 \mathrm{Mg}$ FFB per hectare per year (Table 3). Gomes Jr. et al. (2014) assessed the first two years of bunch production of the same progenies as those used in the present study and found that the most productive were RUB 1210, RUB 1274, RUB 1199, and RUB 1232. In a later study, considering the first four years of production, Gomes Junior et al. (2016) verified that RUB 1199, RUB 1209, 
Table 3. Phenotypic values (PV), genotypic values (GV), and selection gains (SG) for bunch production from the third to the eighth year after planting of 39 progenies of caiaué (Elaeis oleifera) and oil palm (Elaeis guineensis) interspecific hybrids.

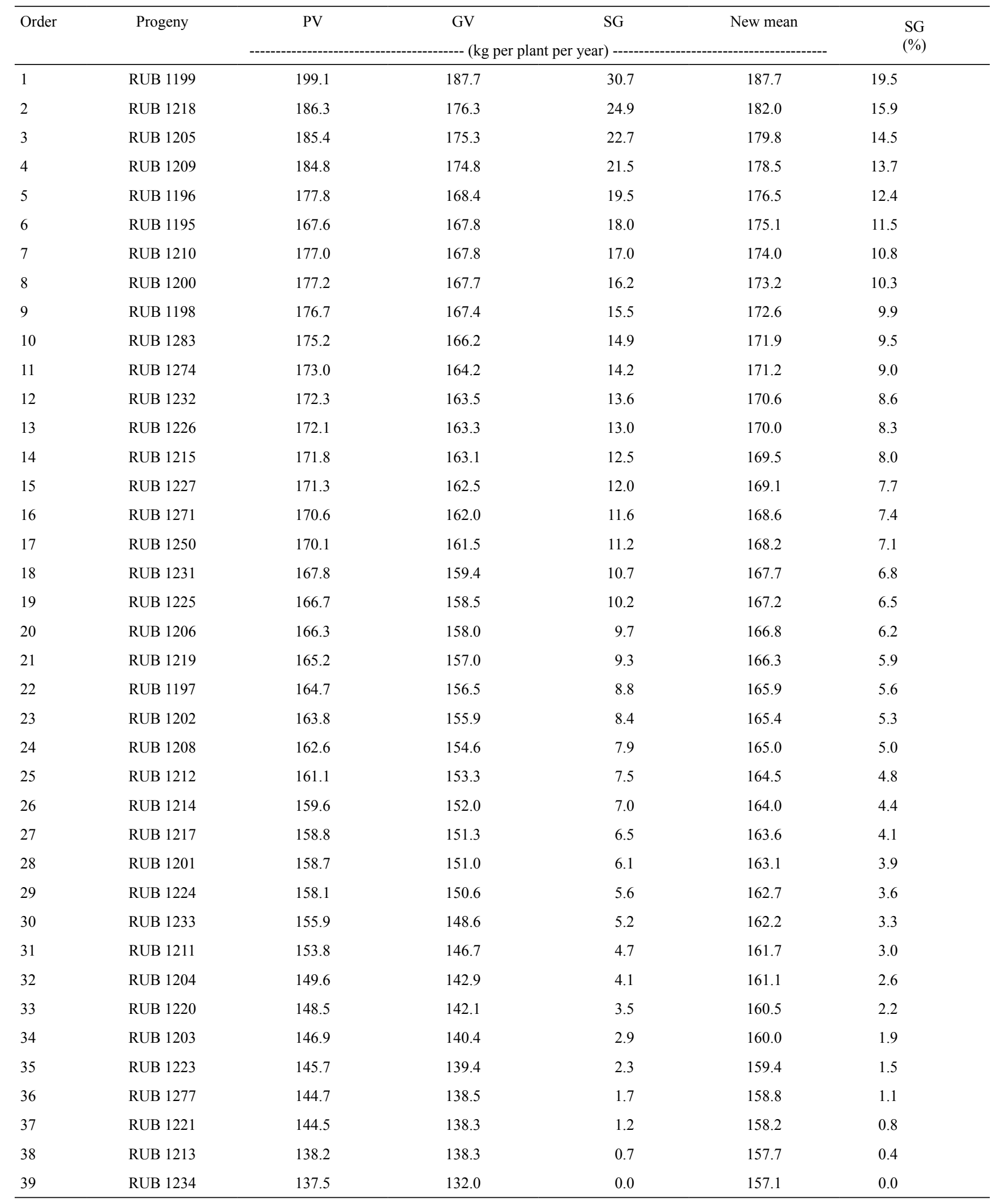


RUB 1218, and RUB 1232 were the most productive. However, only RUB 1199 remained among the four most productive progenies in three consecutive evaluations of brunch production at $1.5,3.5$, and 5.5 years, respectively, indicating the need for longer evaluation periods to obtain greater selection accuracy, as was also concluded by Lopes et al. (2012).

With the selection of the best classified progenies, the selection gain for PROD $_{\text {ind }}$ was $30.7 \mathrm{~kg}$ per plant per year $(19.7 \% \mu \mathrm{GV})$ and the expected mean after selection was $187.7 \mathrm{~kg}$ per plant per year, equivalent to $26.8 \mathrm{Mg}$ FFB per hectare per year. The selection gain with the four best progenies, using a selection pressure of $10.3 \%$, was $21.5 \mathrm{~kg}$ per plant per year, i.e., $13.7 \%$ of the overall mean, and the expected mean after selection was $178.5 \mathrm{~kg}$ per plant per year, which is equivalent to $25.5 \mathrm{Mg}$ FFB per hectare per year. The selection gains for the assessed progenies are comparable to those obtained in other international oil palm breeding programs (Gascon et al., 1988; Bakoumé \& Louise, 2007; Bakoumé et al., 2010; Noh et al., 2012).

To avoid the narrowing of the caiaué genetic basis, as occurred with the Deli, La Mé, Yagambi, and Avros oil palm populations (Soh et al., 2003; Noh et al., 2010; Marhalil et al., 2013), and to maintain the possibility of long-term continuous gains, a lower pressure should be applied in the breeding population to maintain a greater genetic variability. However, to select progenies that will be propagated and made available to producers as new cultivars, the selection pressure should be more intense to guarantee a greater genetic gain than that of current cultivars, leading to greater short-term productivity gains.

For vegetative propagation potential, the mean phenotypic value of the 15 best individuals for PROD $_{\text {ind }}$, using a selection pressure of $0.75 \%$, was $224.8 \mathrm{~kg}$ FFB per plant per year (32.1 Mg FFB per hectare per year), ranging from 210.2 to $256.6 \mathrm{~kg}$ FFB per plant per year (30.0 and 36.7 Mg FFB per hectare per year); in addition, the mean genotypic value was $198.3 \mathrm{~kg}$ FFB per plant per year (28.4 Mg FFB per hectare per year), ranging from 193.4 to $204.2 \mathrm{~kg}$ FFB per plant per year (27.7 to $29.2 \mathrm{Mg}$ FFB per hectare per year) (Table 4). In these individuals, selection gains ranged from 41.2 (26.3\%) to 47.2 (30.0\%) kg FFB per plant per year, i.e., 5.9 to $6.8 \mathrm{Mg}$ FFB per hectare per year, representing a high genetic gain and an excellent potential for the development of new cultivars. The estimates for $\mathrm{PROD}_{\text {ind }}$ of the 15 best individuals $(30.0$ and $36.7 \mathrm{Mg}$ FFB per hectare per year) were higher than those between 26.1 and $31.6 \mathrm{Mg}$ FFB per hectare per year obtained by Lopes et al. (2012) while assessing IEH $\mathrm{F} 1(\mathrm{O} \times \mathrm{G})$ progenies for the selection of individuals for cloning, even though the plants were evaluated in their adult stage, which corresponds to the phase of higher productivity. The capitalization of all genetic effects on selection gain is the main factor contributing to the high selection gains of the individuals selected for cloning when using this strategy, since the genotype is fully reproduced and the allelic frequencies and gene combinations are not altered. Of the 15 individuals with the highest PROD $_{\text {ind }}, 13$ (87\%) are RUB 1199, which is the progeny with the highest genotypic value for $\mathrm{PROD}_{\text {ind }}$; these results are similar to those obtained by Gomes Junior et al. (2016) for the first 3.5 years of production (third to sixth year) in the same population as that assessed in the present study.

As the accuracy in the estimation of genotypic values is lower for individuals than for progenies, a longer period is necessary to reach a high selection accuracy in the evaluation of bunch production. According to Chia et al. (2009), for the selection of IEH $\mathrm{O} \times \mathrm{G}$ families, 4 consecutive years are required for the assessment of bunch production with a good repeatability $(>85 \%)$, and at least 6 years for the selection of individuals with a good accuracy $(>80 \%)$. In the present study, bunch production was evaluated for 5.5 years, and the $\mathrm{C}_{\text {parc }}^{2}$ and $\mathrm{C}^{2}$ int genetic parameters indicate a good accuracy in the selection and cloning of the most productive individuals, which should undergo clonal assessment, with replicates, in different sites to validate their productive performance before being released as new cultivars. Therefore, although breeding programs can provide greater genetic gain, it is necessary to access clones before releasing them, which could take more than 10 years after the selection of individuals, considering the time required for in vitro micropropagation and for evaluating brunch production in the adult stage of the plant, or at least up to 8 years after planting in the field.

Considering the 15 best individuals for $\mathrm{PROD}_{\text {ind }}$ (Table 5), the phenotypic values ranged from 207.9 to $256.6 \mathrm{~kg}$ per plant per year (29.7 to $36.7 \mathrm{Mg}$ FFB per hectare per year), while the genotypic values ranged from 191.4 to $198.8 \mathrm{~kg}$ per plant per year (27.4 to $28.4 \mathrm{Mg}$ 
FFB per hectare per year). The best performing progeny, RUB 1199, accounted for 14 of the 15 individuals with the highest genotypic value, indicating its superiority to the others. The selection of IEH $\mathrm{O} \times \mathrm{G}$ individuals based on additive effects is interesting for the backcrossing strategy, which should be undertaken with the best performing IEH $\mathrm{O} \times \mathrm{G}$ individuals and elite oil palm materials as recurrent parents to establish caiaué resistance to lethal yellowing and improve oil palm productivity and fertility.

For selection among male parents only, the selection gain for the 5 best parents selected from the 13 tested was $10.1 \mathrm{~kg}$ FFB per plant per year $(6.5 \%$, $1.4 \mathrm{Mg}$ FFB per hectare per year), and the new mean was $167.2 \mathrm{~kg}$ FFB per plant per year (23.9 Mg FFB per hectare per year) (Table 6). Of these selected parents, 3 belonged to the LM 13582 family (LM $2 \mathrm{~T}$ progeny) and 2 to the LM 12252 family (LM 10T progeny), being represented by 17 progenies and 811 individuals in the experiment. This high number of individuals confers robustness to the genotypic value estimates of the male parents.
Selection based on the families and progenies of male parents resulted in two better families, LM 13582 (LM 2T progeny) and LM 12252 (LM 10T progeny), which presented a selection gain of $9.5 \mathrm{~kg}$ FFB per plant per year $(6.0 \%, 1.4 \mathrm{Mg}$ FFB per hectare per year), as well as an improved population, with a mean of 166.5 kg FFB per plant per year (23.8 Mg FFB per hectare per year) (Table 6). These families were represented by 7 male parents, 20 progenies, and 950 individuals in the experiment. The selection of the best progeny LM $2 \mathrm{~T}$ - resulted in a selection gain of $6.3 \mathrm{~kg}$ FFB per plant per year $(4.0 \%, 0.9 \mathrm{Mg}$ FFB per hectare per year) and in an improved population, with a mean of 163.4 $\mathrm{kg}$ FFB per plant per year (23.4 Mg FFB per hectare per year). This progeny was represented by 3 families, 6 parents, 15 progenies, and 712 individuals in the experiment.

Combining the studied Manicoré and La Mé populations - from which caiaué and oil palm originated - can lead to selection gains in the short, medium, and long terms through the selection of parents for seed propagation or of individuals for vegetative propagation.

Table 4. Phenotypic values (PV), genotypic values (GV), and selection gains (SG) for bunch production from the third to the eighth year after planting, used to classify the 15 best individuals among 39 progenies of caiaué (Elaeis oleifera) and oil palm (Elaeis guineensis) interspecific hybrids for use in vegetative propagation.

\begin{tabular}{|c|c|c|c|c|c|c|c|}
\hline \multirow{2}{*}{$\begin{array}{l}\text { Clone } \\
\text { order }\end{array}$} & \multirow{2}{*}{$\begin{array}{l}\text { Individual } \\
\text { (line/plant) }^{(1)}\end{array}$} & \multirow[t]{2}{*}{ Progeny } & PV & GV & GS & New mean & \multirow{2}{*}{$\begin{array}{l}\text { SG } \\
(\%)\end{array}$} \\
\hline & & & \multicolumn{4}{|c|}{ - (kg per plant per year) } & \\
\hline 1 & $\mathrm{~L} 124 / \mathrm{P} 15$ & RUB 1205 & 256.6 & 204.2 & 47.2 & 204.2 & 30.0 \\
\hline 2 & L127/P17 & RUB 1199 & 238.7 & 203.4 & 46.8 & 203.8 & 29.8 \\
\hline 3 & L113/P04 & RUB 1199 & 232.6 & 201.9 & 46.1 & 203.2 & 29.4 \\
\hline 4 & $\mathrm{~L} 111 / \mathrm{P} 25$ & RUB 1199 & 231.6 & 201.5 & 45.7 & 202.8 & 29.1 \\
\hline 5 & L124/P17 & RUB 1199 & 234.0 & 201.5 & 45.5 & 202.5 & 28.9 \\
\hline 6 & L126/P19 & RUB 1199 & 232.5 & 200.9 & 45.2 & 202.2 & 28.8 \\
\hline 7 & L125/P17 & RUB 1199 & 225.4 & 198.0 & 44.6 & 201.6 & 28.4 \\
\hline 8 & L109/P24 & RUB 1199 & 222.5 & 197.8 & 44.1 & 201.2 & 28.1 \\
\hline 9 & L113/P02 & RUB 1199 & 220.9 & 197.2 & 43.7 & 200.7 & 27.8 \\
\hline 10 & L115/P02 & RUB 1199 & 220.8 & 197.1 & 43.3 & 200.3 & 27.6 \\
\hline 11 & L109/P25 & RUB 1199 & 216.8 & 195.6 & 42.9 & 199.9 & 27.3 \\
\hline 12 & L112/P05 & RUB 1205 & 234.0 & 194.1 & 42.4 & 199.4 & 27.0 \\
\hline 13 & L115/P04 & RUB 1199 & 212.9 & 193.9 & 42.0 & 199.0 & 26.7 \\
\hline 14 & L104/P07 & RUB 1199 & 210.2 & 193.9 & 41.6 & 198.6 & 26.5 \\
\hline 15 & L124/P19 & RUB 1199 & 214.1 & 193.4 & 41.2 & 198.3 & 26.3 \\
\hline
\end{tabular}

(1)Identification of individuals according to line (L) and plant (P) numbers in the C22 commercial plot of Marborges Agroindústria S.A. (Moju, PA, Brazil). 
Table 5. Phenotypic values (PV) and genotypic values (GV) for bunch production from the third to the eighth year after planting, used to classify the 15 best plants among 39 progenies of caiaué (Elaeis oleifera) and oil palm (Elaeis guineensis) interspecific hybrids for use as parents.

\begin{tabular}{|c|c|c|c|c|}
\hline \multirow{2}{*}{$\begin{array}{l}\text { Order of } \\
\text { parent }\end{array}$} & \multirow{2}{*}{$\begin{array}{l}\text { Individual } \\
\text { (line/plant) }^{(1)}\end{array}$} & \multirow{2}{*}{ Progeny } & $\mathrm{PV}$ & GV \\
\hline & & & \multicolumn{2}{|c|}{ (kg per plant per year) } \\
\hline 1 & L127/P17 & RUB 1199 & 238.7 & 198.8 \\
\hline 2 & L113/P04 & RUB 1199 & 232.6 & 197.8 \\
\hline 3 & $\mathrm{~L} 111 / \mathrm{P} 25$ & RUB 1199 & 231.6 & 197.5 \\
\hline 4 & L124/P17 & RUB 1199 & 234.0 & 197.5 \\
\hline 5 & L126/P19 & RUB 1199 & 232.5 & 197.0 \\
\hline 6 & L124/P15 & RUB 1205 & 256.6 & 195.9 \\
\hline 7 & $\mathrm{~L} 125 / \mathrm{P} 17$ & RUB 1199 & 225.4 & 195.0 \\
\hline 8 & L109/P24 & RUB 1199 & 222.5 & 194.9 \\
\hline 9 & L113/P02 & RUB 1199 & 220.9 & 194.4 \\
\hline 10 & L115/P02 & RUB 1199 & 220.8 & 194.4 \\
\hline 11 & L109/P25 & RUB 1199 & 216.8 & 193.2 \\
\hline 12 & L115/P04 & RUB 1199 & 212.9 & 192.1 \\
\hline 13 & L104/P07 & RUB 1199 & 210.2 & 192.0 \\
\hline 14 & L124/P19 & RUB 1199 & 214.1 & 191.7 \\
\hline 15 & L104/P05 & RUB 1199 & 207.9 & 191.4 \\
\hline
\end{tabular}

(1)Identification of individuals according to line (L) and plant (P) numbers in the C22 commercial plot of Marborges Agroindústria S.A. (Moju, PA, Brazil).

Table 6. Phenotypic value (PV), genotypic value (GV), selection gain (SG), and new mean (NM) for bunch production based on the GV of the 39 progênies of caiaue (Elaeis oleifera) and oil palm (Elaeis guineensis) interspecific hybrids from the Manicoré (female) and La Mé (male) populations, respectively, evaluated for brunch production from the third to the eighth year after planting.

\begin{tabular}{|c|c|c|c|c|c|c|c|c|c|}
\hline \multicolumn{5}{|c|}{ Progenies genealogy and representation considering male parents from La Mé (LM) population } & PV & GV & SG & NM & \multirow{2}{*}{$\begin{array}{l}\mathrm{SG}^{(1)} \\
(\%)\end{array}$} \\
\hline Parent & $\begin{array}{l}\text { Parent } \\
\text { family }\end{array}$ & $\begin{array}{l}\text { Family } \\
\text { origin }\end{array}$ & $\begin{array}{c}\text { Number of } \\
\text { progenies }\end{array}$ & $\begin{array}{l}\text { Number of } \\
\text { individuals }\end{array}$ & \multicolumn{4}{|c|}{----------(kg per plant per year)---------- } & \\
\hline RU 2693 P & LM 13582 & LM 2T & 5 & 239 & 173.8 & 170.5 & 13.5 & 170.5 & 8.6 \\
\hline RU $2692 \mathrm{P}$ & LM 13582 & LM $2 \mathrm{~T}$ & 4 & 189 & 174.4 & 170.4 & 13.4 & 170.5 & 8.6 \\
\hline RU $2700 \mathrm{P}$ & LM 12252 & LM $10 \mathrm{~T}$ & 5 & 240 & 168.9 & 166.3 & 12.0 & 169.1 & 7.7 \\
\hline RU $2691 \mathrm{P}$ & LM 13582 & LM 2T & 2 & 96 & 173.8 & 164.5 & 10.9 & 167.9 & 7.0 \\
\hline RU 2733 P & LM 12252 & LM $10 \mathrm{~T}$ & 1 & 47 & 184.8 & 164.1 & 10.1 & 167.2 & 6.5 \\
\hline RU 56 P & LM 12011 & LM 10T & 4 & 285 & 165.6 & 159.6 & 8.9 & 165.9 & 5.7 \\
\hline RU 2749 P & LM 13582 & LM $2 \mathrm{~T}$ & 2 & 93 & 168.1 & 159.5 & 7.9 & 165.0 & 5.1 \\
\hline RU $2730 \mathrm{P}$ & LM 13751 & LM 10T & 6 & 282 & 160.6 & 159.4 & 7.2 & 164.3 & 4.6 \\
\hline RU 2707 P & LM 12437 & LM $2 \mathrm{~T}$ & 1 & 47 & 176.7 & 157.1 & 6.4 & 163.5 & 4.1 \\
\hline RU 53 P & LM 12785 & LM $2 \mathrm{~T}$ & 1 & 48 & 172.1 & 153.3 & 5.4 & 162.5 & 3.5 \\
\hline RU $2710 \mathrm{P}$ & LM 12011 & LM 10T & 6 & 372 & 143.8 & 143.8 & 3.7 & 160.8 & 2.4 \\
\hline RU $2729 \mathrm{P}$ & LM 13751 & LM 10T & 1 & 48 & 158.1 & 141.3 & 2.1 & 159.2 & 1.3 \\
\hline RU $2698 \mathrm{P}$ & LM 12252 & LM 10T & 1 & 46 & 146.9 & 131.8 & 0.0 & 157.1 & 0.0 \\
\hline \multirow{2}{*}{$\begin{array}{l}\text { Parent } \\
\text { family }\end{array}$} & \multirow{2}{*}{$\begin{array}{c}\text { Family } \\
\text { origin }\end{array}$} & \multirow{2}{*}{$\begin{array}{c}\text { Number of } \\
\text { parents }\end{array}$} & \multirow{2}{*}{$\begin{array}{l}\text { Number of } \\
\text { progenies }\end{array}$} & \multirow{2}{*}{$\begin{array}{l}\text { Number of } \\
\text { individuals }\end{array}$} & PV & GV & SG & $\mathrm{NM}$ & SG \\
\hline & & & & & \multicolumn{4}{|c|}{-----------(kg per plant per year)---------- } & $(\%)$ \\
\hline LM 13582 & LM 2T & 4 & 13 & 617 & 172.9 & 169.5 & 12.5 & 169.5 & 8.0 \\
\hline LM 12252 & LM 10T & 3 & 7 & 333 & 168.1 & 163.5 & 9.5 & 166.5 & 6.0 \\
\hline LM 13751 & LM 10T & 2 & 7 & 330 & 160.2 & 156.4 & 6.1 & 163.1 & 3.9 \\
\hline LM 12437 & LM $2 \mathrm{~T}$ & 1 & 1 & 47 & 176.7 & 154.0 & 3.8 & 160.8 & 2.4 \\
\hline LM 12785 & LM $2 \mathrm{~T}$ & 1 & 1 & 48 & 172.1 & 150.2 & 1.7 & 158.7 & 1.1 \\
\hline LM 12011 & LM 10T & 2 & 10 & 657 & 153.2 & 148.7 & 0.0 & 157.1 & 0.0 \\
\hline \multirow{2}{*}{ Origin } & \multirow{2}{*}{$\begin{array}{l}\text { Number of } \\
\text { families }\end{array}$} & \multirow{2}{*}{$\begin{array}{l}\text { Number of } \\
\text { parents }\end{array}$} & \multirow{2}{*}{$\begin{array}{l}\text { Number of } \\
\text { progenies }\end{array}$} & \multirow{2}{*}{$\begin{array}{l}\text { Number of } \\
\text { individuals }\end{array}$} & PV & $\mathrm{GV}$ & SG & $\mathrm{NM}$ & SG \\
\hline & & & & & \multicolumn{4}{|c|}{----------(kg per plant per year)--------- } & $(\%)$ \\
\hline LM 2T & 3 & 6 & 15 & 712 & 173.1 & 163.4 & 6.3 & 163.4 & 4.0 \\
\hline LM 10T & 3 & 7 & 24 & 1,320 & 158.7 & 150.7 & 0.0 & 157.1 & 0.0 \\
\hline
\end{tabular}

${ }^{(1)} \mathrm{SG}$ was estimate considering only male parents selection, at the parent, family, and origin level. 


\section{Conclusions}

1. Short-term genetic gains for bunch production in interspecific hybrids between caiaué (Elaeis oleifera) and oil palm (Elaeis guineensis) (IEH $\mathrm{O} \times \mathrm{G})$ can be obtained if selection is restricted to male parents, while medium-term gains can be achieved through the selection of both male and female parents and cloning of F1 individuals.

2. Progenies of IEH $\mathrm{O} \times \mathrm{G}$ exhibit high genetic variability for bunch production from the third to the eighth year after planting.

3. By selecting improved IEH $\mathrm{O} \times \mathrm{G}$ individuals based on additive effects, selection gains for long-term bunch production can be obtained from backcrosses that use oil palm as the recurrent parent.

\section{Acknowledgments}

To Marborges Agroflorestal S.A., for providing the infrastructure for the experiments and for financial support; and to Conselho Nacional de Desenvolvimento Científico e Tecnológico (CNPq) and to Fundação Amazônia de Amparo a Estudos e Pesquisas (Fapespa), for financial support.

\section{References}

ALVARES, C.A.; STAPE, J.L.; SENTELHAS, P.C.; GONCCALVES, J.L. de M.; SPAROVEK, G. Köppen's climate classification map for Brazil. Meteorologische Zeitschrift, v.22, p.711-728, 2013. DOI: https://doi.org/10.1127/09412948/2013/0507.

BAKOUMÉ, C.; GALDIMA, M.; TENGOUA, F.F. Experimental modification of reciprocal recurrent selection in oil palm breeding in Cameroon. Euphytica, v.171, p.235-240, 2010. DOI: https://doi.org/10.1007/s10681-009-0034-1.

BAKOUMÉ, C.; LOUISE, C. Breeding for oil yield and short oil palms in the second cycle of selection at La Dibamba (Cameroon). Euphytica, v.156, p.195-202, 2007. DOI: https://doi.org/10.1007/ s10681-007-9366-X.

BRASIL. Ministério da Agricultura, Pecuária e Abastecimento. Registro Nacional de Cultivares - RNC. Registro $n^{\circ} 26031$. Disponível em: < http://sistemas.agricultura.gov.br/snpc/ cultivarweb/cultivares_registradas.php>. Acesso em: Oct. 24 2019.

CADENA, T.; PRADA, F.; PEREA, A.; ROMERO, H.M. Lipase activity, mesocarp oil content, and iodine value in oil palm fruits of Elaeis guineensis, Elaeis oleifera, and the interspecific hybrid $\mathrm{O} \times \mathrm{G}(E$. oleifera $\mathrm{x}$ E. guineensis). Journal of the Science of Food and Agriculture, v.93, p.674-680, 2013. DOI: https://doi.org/10.1002/jsfa.5940.
CHIA, G.S.; LOPES, R.; CUNHA, R.N.V. da; ROCHA, R.N.C. da; LOPES, M.T.G. Repetibilidade da produção de cachos de híbridos interespecíficos entre o caiaué e o dendezeiro. Acta Amazônica, v.39, p.249-254, 2009. DOI: https://doi.org/10.1590/ S0044-59672009000200001.

CUNHA，R.N.V. da; LOPES, R. BRS Manicoré: híbrido interespecífico entre o caiaué e o dendezeiro africano recomendado para áreas de incidência de amarelecimento-fatal. Manaus: Embrapa Amazônia Ocidental, 2010. 3p. (Embrapa Amazônia Ocidental. Comunicado técnico, 85).

DE FRANQUEVILLE, H. Oil palm rot in Latin America. Experimental Agriculture, v.39, p.225-240, 2003. DOI: https://doi.org/10.1017/S0014479703001315.

FAO. Food and Agriculture Organization of the United Nations. Faostat: production crops. 2017. Available at: $<$ http://www.fao. org/faostat/en/\#data/QC>. Accessed on: Feb. 22019

GASCON, J.P.; LE GUEN, V.; NOUY, B.; ASMADY; KAMGA, F. Résultats d'essais de second cycle de sélection récurrente réciproque chez le palmier à huile Elaeis guineensis Jacq. Oléagineux, v.43, p.6-7, 1988.

GOMES JR., R.A.; GURGEL, F. de L.; PEIXOTO, L. de A.; BHERING, L.L.; CUNHA, R.N.V. da; LOPES, R.; PINA, A.J. de A.; VEIGA, A.S. Evaluation of interspecific hybrids of palm oil reveals great genetic variability and potential selection gain. Industrial Crops and Products, v.52, p.512-518, 2014. DOI: https://doi.org/10.1016/j.indcrop.2013.10.036.

GOMES JUNIOR, R.A.; LOPES, R.; CUNHA, R.N.V. da; PINA, A.J. de A.; QUARESMA, C.E.; SANTOS, R.R.; RESENDE, M.D.V. de. Bunch yield of interspecific hybrids of American oil palm with oil palm in the juvenile phase. Croop Breeding and Applied Biotechnology, v.16, p.86-94, 2016. DOI: https://doi.org/10.1590/1984-70332016v16n2a14.

GOMES JUNIOR, R.A; PINA, A.J. de A; GURGEL, F. de L.; FRANZINI, V.I.; CARVALHO, E. de A.; VEIGA, A.S.; BHERING, L.L.; CUNHA, R.N.V. da. Sistema de produção de mudas em híbridos interespecíficos entre caiaué e dendê. Ciência Florestal, v.27, p.169-179, 2017.

LIEB, V.M.; KERFERS, M.R.; KRONMÜLLER, A.; ESQUIVEL, P.; ALVARADO, A.; JIMÉNEZ, V.M.; SCHMARR, H.-G.; CARLE， R.; SCHWEIGGERT, R.M.; STEINGASS, C.B. Characterization of mesocarp and kernel lipids from Elaeis guineensis Jacq., Elaeis oleifera [Kunth] Cortés, and their interspecific hybrids. Journal of Agricultural and Food Chemistry, v.65, p.3617-3626, 2017. DOI: https://doi.org/10.1021/ acs.jafc.7b00604.

LOPES, R.; CUNHA, R.N.V. da; RESENDE, M.D.V. de. Produção de cachos e parâmetros genéticos de híbridos de caiaué com dendezeiro. Pesquisa Agropecuária Brasileira, v.47, p.1496-1503, 2012. DOI: https://doi.org/10.1590/S0100204X2012001000012.

MARHALIL, M.; RAFII, M.Y.; AFIZI, M.M.A.; AROLU, I.W.; NOH, A.; MOHD DIN, A.; KUSHAIRI, A.; NORZIHA, A.; RAJANAIDU, N.; LATIF, M.A.; MALEK, M.A. Genetic variability in yield and vegetative traits in elite germplasm of MPOB-Nigerian dura x AVROS pisifera progenies. Journal of Food, Agriculture \& Environment, v.11, p.515-519, 2013. 
MENEZES, A.J.E.A. de; HOMMA, A.K.O.; GOMES JÚNIOR, R.A.; FUJIYAMA, B.S.; SANTOS, J.C. dos. Práticas tecnológicas adotadas pelos produtores de dendezeiro híbrido interespecífico no nordeste paraense. Belém: Embrapa Amazônia Oriental, 2017. 42p. (Embrapa Amazônia Oriental. Documentos, 430).

NOH, A.; RAFII, M.Y.; SALEH, G.; KUSHAIRI, A. Genetic performance of 40 Deli dura x Avros pisifera full-sib families. Journal of Oil Palm Research, v.22, p.781-795, 2010.

NOH, A.; RAFII, M.Y.; SALEH, G.; KUSHAIRI, A.; LATIF, M.A. Genetic performance and general combining ability of oil palm Deli dura x AVROS pisifera tested on inland soils. The Scientific World Journal, v.2012, art. ID 792601, 2012. DOI: https://doi.org/10.1100/2012/792601.

OKOYE, M.N.; OKWUAGWU, C.O.; UGURU, M.I. Population improvement for fresh fruit bunch yield and yield components in oil palm (Elaeis guineensis Jacq.). American-Eurasian Journal of Scientific Research, v.4, p.59-63, 2009.

OKWUAGWU, C.O.; OKOYE, M.N.; OKOLO, E.C.; ATAGA, C.D.; UGURU, M.I. Genetic variability of fresh fruit bunch yield in Deli/dura $\times$ tenera breeding populations of oil palm (Elaeis guineensis Jacq.) in Nigeria. Journal of Tropical Agriculture, v.46, p.52-57, 2008.

PINA, A.J.A. Experiências na produção para a cultura de palma de óleo na Amazônia: relato de experiências da Marborges
Agroindústria S.A. (Moju - Pará). In: RAMALHO FILHO, A.; MOTTA, P.E.F. da; FREITAS, P.L. de; TEIXEIRA, W.G. Zoneamento agroecológico, produção e manejo dendezeiro Amazônia. Rio de Janeiro: Embrapa Solos, 2010. p.189-204.

RESENDE, M.D.V. de. Matemática e estatística na análise de experimentos e no melhoramento genético. Colombo: Embrapa Florestas, 2007. 561p.

RESENDE, M.D.V. de. Software Selegen - REML/BLUP. Colombo: Embrapa Florestas, 2002. 67p. (Embrapa Florestas. Documentos, 77).

SANTOS, H.G. dos; JACOMINE, P.K.T.; ANJOS, L.H.C. dos; OLIVEIRA, V.A. de; LUMBRERAS, J.F.; COELHO, M.R.; ALMEIDA, J.A. de; CUNHA, T.J.F.; OLIVEIRA, J.B. de. . Sistema brasileiro de classificação de solos. 3.ed. rev. e ampl. Brasília: Embrapa, 2013. 353p.

SOH, A.C.; GAN, H.H.; WONG, G.; HOR, T.Y.; TAN, C.C. Estimates of within family genetic variability for clonal selection in oil palm. Euphytica, v.133, p.147-163, 2003.

ZIMMER, Y. Cost competitiveness of major oilseeds versus palm oil. 2009. Available at: <http://www.agribenchmark. org/fileadmin/Dateiablage/B-Cash-Crop/Team-Publications/ Zimmer_oilseeds_2009.pdf>. Accessed on: Feb. 262019. 